Функциональное состояние шишковидной железы, изменяемое содержанием животных в условиях постоянного освещения или постоянной темноты, влияет на результат действия гипоксии на содержание ОБМ в тканях десны. Высокий уровень продукции мелатонина шишковидной железой (содержание животных в условиях темноты) усиливает понижающее действие гипоксии на уровень ОМБ, что проявляется более выражено у самцов.

Таким образом, путем сочетанного действия прерывистой гипобарической гипоксии и постоянной темноты можно предотвратить накопление окисленных белков в тканях десны неполовозрелых животных.

Кючевые слова: десна, гипоксия, фотопериод, окислительно-модифицированные белки, пол.

\title{
THE SEX RELATED EFFECTS OF INTERMITTENT HYPOBARIC HYPOXIA ON THE OXIDIZED MODIFICATION OF PROTEINS IN THE GINGIVAL TISSUES IN IMMATURE RATS UNDER CONDITIONS OF CHANGED PHOTOPERIOD
}

\section{R.R. Dmytrenko, H.I. Khodorovskyi, V.A. Honcharenko}

Abstract. It is shown in experiments that intermittent hypoxia (equivalent to the altitude 4000 meters, 2 hours per day for 14 days) changes the capacity of the oxidized modification of proteins (OMP) in the gingival tissues of immature albino rats. The result of hypoxic effects depends on the sex of animals: in males it causes a decrease of proteins peroxidation intensity both of basic and neutral nature; in females - only a tendency to decrease of the basic OMP.

Functional state of the pineal gland changed by experimental conditions (14 days of illumination - "physiological pinealectomy", or 14 days of darkness - stimulation of the pineal gland) influenced the effects of hypoxia on the OMP in the gingival tissues. The darkness heightens the decreasing effects of hypoxia on the capacity of OMP in the gingival, which is more pronounced in male rats.

Our results suggest that by an application of combination of intermittent hypobaric hypoxia and the darkness it is possible to prevent the process of accumulation of OMP in the gingival tissues

Key words: gingiva, hypoxia, photoperiod, oxidized modification of proteins, sex.

Bukovinian State Medical University (Chernivnsi)

Рецензент - проф. Р.С. Булик
Buk. Med. Herald. - 2014. - Vol. 18, № 1 (69). - P. 29-32

Надійшла до редакції 30.01.2014 року

(C) Р.Р. Дмитренко, Г.І. Ходоровський, В.А. Гончаренко, 2014

УДК 616.831.9-002.155:616-008.8-097-009

Д.А. Задирака, О.В. Рябоконь, А.В. Абрамов

\section{ОСОБЛИВОСТІ ФУНКЦІОНАЛЬНОГО СТАНУ НЕЙРОГУМОРАЛЬНОЇ РЕГУЛЯЦЇ̈ У ХВОРИХ НА СЕРОЗНІ МЕНІНГІТИ В ДИНАМІЦ ЗАХВОРЮВАННЯ}

Запорізький державний медичний університет

Резюме. У роботі показано, що у хворих на серозні менінгіти в динаміці захворювання на тлі зменшення загальноінтоксикаційної й загальномозкової симптоматики маніфестують клінічні ознаки вегетативної дисфункції, що підтверджуються змінами варіабельності

Вступ. Інфекційні хвороби з ураженням нервової системи - одна 3 найактуальніших проблем сучасної клінічної медицини $[1,2]$. Згідно $з$ даними Європейської Федерації Неврологічних Товариств (EFNS), серозний менінгіт (CM) реєструється з частотою 2-5 на 100 тис. людей у країнах Свропи і може бути в десятки разів вищим у менш розвинутих країнах. СМ входить до першої десятки причин смерті, пов'язаних з інфекційними хворобами у світі, а 30-50 \% осіб, які одужали, мають постійні неврологічні ускладнення, серед яких когнітивна дисфункція, поведінкові розлади, судоми та рухові розлади, церебрастенічний, астеноневротичний, лікворно-гіпертензійний і діенцефальний синдроми $[13,16,20]$.

(С) Д.А. Задирака, О.В. Рябоконь, А.В. Абрамов, 2014

32 серцевого ритму й гормональними змінами та зберігаються в більшості хворих і в періоді реконвалесценції.

Ключові слова: серозний менінгіт, варіабельність серцевого ритму, гормони.

Сучасні уявлення про типові патологічні процеси та їх реалізацію в нозологічну форму свідчать, що в основі розвитку захворювання лежить деформація системної реакції організму на дію етіологічних чинників. При цьому ключовою складовою генезу патологічного процесу виступає зміна або порушення спроможності компенсаторно-пристосувальних механізмів [16, 17]. У першу чергу, це стосується нейроендокринної системи, яка запускає реакції адаптації та/або компенсації до будь-якого зовнішнього впливу, ареактивність центральних регуляторних систем може змінюватися не лише кількісно, але і якісно. При цьому гіпоергічна реакція системи може 
за певних умов змінитися на гіперергічну або навіть на дизергічну $[7,11]$. Крім того, слід зазначити, що нейроімуноендокринні взаємодії визначають перебіг інфекції, а дисбаланс гормонального статусу призводить до нейроімунної дизрегуляції. Доведено, що адекватна імунна відповідь забезпечується «нормальним» гормональним гомеостазом [9]. Відомий зв'язок розвитку багатьох автоімунних захворювань із віковими гормональними перебудовами, що зумовлено впливом гормонів на імунну систему, опосередковується через безліч специфічних рецепторів, представлених на імунокомпетентних клітинах $[19,22]$.

Мета дослідження. Дослідити особливості змін параметрів вегетативного гомеостазу у хворих на серозні менінгіти в динаміці захворювання.

Матеріал і методи. Під спостереженням у відділенні нейроінфекцій Запорізької обласної інфекційної лікарні було 68 хворих на СМ (чоловіків - 40; жінок - 28). Вік пацієнтів коливався від 19 до 84 років. СМ у всіх осіб підтверджено результатами цитологічного й біохімічного дослідження ліквору. Для розшифровки етіології СМ застосовані методи полімеразної ланцюгової реакції та імуноферментного аналізу. Всі пацієнти залучені в дослідження за випадковою ознакою та за інформованої згодою.

Аналіз результатів специфічної лабораторної діагностики дав змогу зазначити, що серед пацієнтів із СМ у 8 (11,8 \%) випадках зафіксована герпесвірусна етіологія менінгіту. У кожного десятого пацієнта (7 - 10,3\%) ураження м'яких мозкових оболонок зумовлене вірусом лихоманки західного Нілу. У

2 (2,9 \%) випадках етіологічним чинником були ентеровіруси Коксаки В5, в 1 (1,5\%) пацієнта - аденовірус. В 1 (1,5\%) пацієнта ураження ЦНС зумовлене мікст-вірусною інфекцією Епштейна-Барра та Коксаки В5. Однак, незважаючи на сучасні можливості специфічної лабораторної діагностики, у більшості хворих на СМ уточнити етіологічний чинник не вдалося (49 - 72,1 \%). Всі пацієнти отримували традиційну базисну терапію, яка включала призначення ацикловіру за умов підтвердження герпесвірусного генезу СМ, інтерферону, нестероїдні протизапальні засоби, ноотропи, вітаміни групи В, засоби, які покращують мозковий кровообіг та метаболізм, при тяжкому перебігу - глюкокортикостероїди, за необхідності антибактеріальну терапію.

Для виявлення клінічних ознак вегетативної дисфункції використовували опитувальник Вейна. Наявність синдрому вегетативної дистонії реєстрували в пацієнтів, які набрали понад 15 балів за опитувальником Вейна [13].

Функціональний стан ВНС визначали методом комп'ютерної кардіоінтервалометрії [21] 3 використанням електрокардіографічної діагностичної системи CardioLab 2000. Аналізували спектральні параметри варіабельності ритму серця (BPC): Totalpower, мс2 - дисперсія R-R інтервалів на всьому сегменті 0,000-0,400 Гц; VLF,
$\mathrm{Mc}^{2}$ - потужність у діапазоні дуже низьких частот 0,003-0,040 Гц; LF, мc ${ }^{2}-$ потужність у діапазоні низьких частот 0,040-0,150 Гц; НF, мс ${ }^{2}-$ потужність у діапазоні високих частот 0,150-0,400 Гц; LFnorm, HFnorm, \% - відносні показники, які відображають внесок кожного спектрального компонента в спектр нейрогуморальної регуляції; LF/HF - індекс вегетативного балансу.

Методом імуноферментного аналізу визначали вміст у сироватці крові адренокортикотропного гормону(АКТГ) (Biomerica, Germany) та соматотропного гормону (СТГ) (DBC, Canada). Контрольну групу склали 20 здорових осіб. Всі спеціальні лабораторні дослідження здійснено в ЦНДЛ ЗДМУ (завідувач - д.мед.н., професор А.В. Абрамов ).

Результати досліджень статистично опрацьовано 3 використанням сформованої бази даних обстежених пацієнтіві здорових осіб у програмі «STATISTICA ${ }^{\circledR}$ for Windows 7.0». Обчислювали середні значення (M), середні похибки середньої арифметичної (m). Для оцінки достовірності різниці кількісних ознак між незалежними вибірками застосовували критерій Манна-Уїтні, між залежними вибірками - критерій Вілксона. Для оцінки ступеня зв'язку між ознаками застосовували метод рангової кореляції Спірмена 3 обчисленням коефіцієнта кореляції (r).

Результати дослідження та їх обговорення. На момент госпіталізації клінічна картина СМ у більшості хворих, незалежно від етіології процесу, характеризувалася гострим початком із перевагою симптомів загальноінтоксикаційного та загальномозкового синдромів. За результатами аналізу загальноінтоксикаційної симптоматики виявлено, що підвищення температури тіла від субфебрильних цифр до гіпертермії зафіксовано у $66(97,1 \%)$ обстежених, загальну слабкість відмічали 55 (80,9 \%), зниження апетиту - 43 (63,2 \%) хворих на СМ. Загальномозковий синдром характеризувався наявністю цефалгії різного ступеня вираженості та локалізації, на яку скаржилися всі хворі, нудоту відмічали 42 (61,8 \%) обстежених, одноразове чи повторне блювання, яке не приносило полегшення та не пов'язане 3 прийомом їжі - 31 (45,6 \%) пацієнт, болючість при пальпації, русі очних яблук та фотофобію - 63 (92,6 \%) хворих. Менінгіальний синдром реєструвався у 66 (97,1 \%) обстежених. Слід зазначити великий відсоток спостереження нестійкості та дисоціації менінгеального синдрому (42 - 61,8 \%). У 2 (2,9\%) осіб менінгеальні ознаки були відсутні, і лише наявність стійкої лихоманки та постійного головного болю дали змогу обгрунтувати необхідність проведення діагностичної люмбальної пункції.

На момент госпіталізації, у більшості пацієнтів (49 - 72,1 \%) спостерігалися певні клінічні прояви вегетативної дисфункції у вигляді пастурального тремору повік та верхніх кінцівок при виконанні пальце-носової проби. У дебюті СМ ознаки вегетативної дисфункції можна було зафіксувати лише при об’єктивному огляді пацієнтів. 
Показники варіабельності ритму серця у хворих на серозний менінгіт у динаміці захворювання $(\mathrm{M} \pm \mathbf{m})$

\begin{tabular}{|c|c|c|c|c|}
\hline \multirow{2}{*}{ Показник } & \multirow{2}{*}{$\begin{array}{c}\text { Здорові особи } \\
(\mathrm{n}=20)\end{array}$} & \multicolumn{3}{|c|}{ Хворі на СМ (n=68) } \\
\cline { 3 - 5 } & & при госпіталізації $(\mathrm{n}=68)$ & через 7 діб $(\mathrm{n}=68)$ & при виписці(n=32) \\
\hline Totalpower, мc & $2032,35 \pm 193,68$ & $1492,34 \pm 163,28^{*}$ & $1433,08 \pm 127,43^{*}$ & $1819,69 \pm 141,68$ \\
\hline VLF, мc & $1211,75 \pm 157,69$ & $733,96 \pm 92,89^{*}$ & $712,51 \pm 99,32^{*}$ & $819,13 \pm 68,72^{*}$ \\
\hline LF, мc ${ }^{2}$ & $897,73 \pm 99,49$ & $513,97 \pm 67,93^{*}$ & $504,82 \pm 61,84^{*}$ & $603,87 \pm 45,08^{*}$ \\
\hline LF norm, \% & $61,5 \pm 2,353$ & $48,1 \pm 2,3^{*}$ & $46,9 \pm 1,9^{*}$ & $54,2 \pm 2,5$ \\
\hline HF, мc ${ }^{2}$ & $728,04 \pm 71,53$ & $580,67 \pm 92,65^{*}$ & $603,12 \pm 80,74^{*}$ & $522,40 \pm 40,29^{*}$ \\
\hline HF norm, \% & $39,07 \pm 2,4$ & $52,0 \pm 2,3^{*}$ & $52,9 \pm 1,9^{*}$ & $45,5 \pm 2,5^{*}$ \\
\hline LF/HF & $1,77 \pm 0,18$ & $1,22 \pm 0,11^{*}$ & $1,2 \pm 0,09^{*}$ & $1,47 \pm 0,16$ \\
\hline
\end{tabular}

Примітка. 1. * - різниця достовірна порівняно зі здоровими особами $(\mathrm{p}<0,04-0,0009)$

Таблищя 2

\section{Вміст адренокортикотропного та соматотропного гормонів у сироватці крові хворих на СМ} у динаміці захворювання (M \pm m)

\begin{tabular}{|c|c|c|c|c|}
\hline \multirow{2}{*}{ Показник } & \multirow{2}{*}{$\begin{array}{c}\text { Здорові особи } \\
(\mathrm{n}=20)\end{array}$} & \multicolumn{3}{|c|}{ Хворі на СМ (n=68) } \\
\cline { 3 - 5 } & & при госпіталізації $(\mathrm{n}=68)$ & через 7 діб $(\mathrm{n}=68)$ & при виписці(n=32) \\
\hline АКТГ, нг/мл & $6,706 \pm 0,348$ & $9,868 \pm 1,007^{*}$ & $11,172 \pm 1,372^{*} * *$ & $9,475 \pm 1,195$ \\
\hline СТГ, нг/мл & $3,318 \pm 0,623$ & $1,548 \pm 0,124^{*}$ & $0,766 \pm 0,085^{*} * *$ & $2,903 \pm 0,429^{*}$ \\
\hline
\end{tabular}

Примітка. 1. *- різниця достовірна порівняно зі здоровими особами (р<0,02-0,004); 2 *** - 3 показниками при госпіталізації ( $<<0,02-0,0008)$

За результатами проведених досліджень ВРС у хворих на СМ при госпіталізації зареєстровано зниження ( $<0,007-0,0004)$, порівняно з показниками здорових осіб, загальної потужності спектра BPC (Totalpower), потужності спектра впливу гуморальних систем (VLF), а також потужності спектра низькочастотних коливань (LF) та потужності спектра високочастотних коливань (HF), які відображають відповідно активність симпатичного та парасимпатичного відділів ВНС. Подальший порівняльний аналіз спектральних параметрів ВРС показав наявність вегетативного дисбалансу в бік парасимпатикотонії, що проявився збільшенням $(\mathrm{p}<0,004)$ частки парасимпатичних впливів (HF norm) у загальному спектрі вегетативної регуляції і зниженням ( $<<0,003-0,004)$ частки симпатичних впливів (LF norm) та індексу вегетативного балансу (LF/HF) (табл. 1).

Зміни функціонального стану ВНС у хворих на СМ вже при госпіталізації поєднувалися зі зрушеннями ендокринних показників, а саме підвищенням $(\mathrm{p}<0,04)$ вмісту в сироватці крові АКТГ на $47,2 \%$ та зниженням $(\mathrm{p}<0,04)$ рівня СТГ на $53,4 \%$ (табл. 2).

Спостереження за хворими на СМ у динаміці показало, що через тиждень лікування відбулася позитивна динаміка щодо зменшення виразності загальноінтоксикаційного синдрому, трива- лість якого в середньому склала $(6,6 \pm 0,4)$ діб, а нормалізація температури тіла відбулася в середньому на $(3,5 \pm 0,3)$ день, зменшилася вираженість менінгеального та цефалгічного синдромів. Проте 3 другого тижня стаціонарного лікування у хворих на СМ почали переважати симптоми вегетативної дисфункції. Більшість пацієнтів скаржилися на підвищену стомлюваність $(48-70,6$ \%), яка посилювалася у другій половині доби, 34 (50 \%) пацієнти відзначали періодичний головний біль, часто пов'язаний зі зміною метеоумов, $26(38,2 \%)$ - підвищене потовиділення, 28 $(41,2 \%)$ - розлади сну, 30 (44,1\%) - серцебиття, у $40(58,8 \%)$ - зберігався пастуральний тремор повік та верхніх кінцівок, який підсилювався при інтенції. Наявність вегетативної дисфункції на 2му тижні лікування підтверджено сумою балів $(25,7 \pm 0,6)$ при проведенні опитування пацієнтів за шкалою Вейна.

Поглиблення змін нейроендокринної регуляції на другому тижні базисного лікування хворих на СМ підтверджують триваюче підвищення $(\mathrm{p}<0,02)$ вмісту в сироватці крові АКТГ та зниження $(\mathrm{p}<0,0008)$ рівня СТГ (табл. 2) при відсутності ( $>00,05)$ змін спектральних параметрів ВРС (табл. 1), порівняно з відповідними показниками осіб при госпіталізації. 
Базисна терапія, яку отримували хворі на СМ у стаціонарі, сприяла регресу симптомів вегетативної дисфункції. У більшості осіб підвищена стомлюваність зникла на $(15,9 \pm 0,7)$ добу, головний біль - на $(15,3 \pm 0,4)$ добу, розлади сну - на $(16,0 \pm 0,4)$ добу, потовиділення - на $(15,8 \pm 0,4)$ добу, відчуття серцебиття - на $(16,1 \pm 0,4)$ добу, пастурального тремору - на $(15,9 \pm 0,5)$ добу. Про зменшення клінічних проявів вегетативної дисфункції на тлі базисної терапії свідчило й зниження середнього бала за опитувальником Вейна до $(17,8 \pm 0,9)$ балів $(\mathrm{p}<0,0001)$, порівняно 3 попереднім періодом спостереження. Проте на момент виписки зі стаціонару в певної кількості пацієнтів зберігалися клінічні ознаки вегетативних розладів у вигляді швидкої стомлювальності - у 7 (21,9 \%), цефалгії - у 5 (15,6 \%), розладів сну - у 4 (12,5\%), потовиділення - у 8 (25\%), серцебиття у 12 (37,5\%), пастурального тремору - у 10 (31,6\%) пацієнтів.

На момент виписки хворих на СМ зі стаціонару наявність вегетативного дисбалансу підтверджено низькими ( $<<0,04-0,005)$, порівняно зі здоровими особами, показниками потужності спектра гуморальних впливів (VLF), симпатичної (LF) та парасимпатичної (HF) активності, а також вищою $(\mathrm{p}<0,04)$ часткою парасимпатичних впливів у загальному спектрі вегетативної регуляції (HFnorm) (табл. 1). На тлі вегетативного дисбалансу в бік парасимпатикотонії вміст СТГ у сироватці крові залишався нижчим $(\mathrm{p}<0,02)$, ніж у здорових осіб.

Кореляційний аналіз дозволив зареєструвати пряму кореляцію між вмістом у сироватці крові СТГ та показниками LFnorm $(\mathrm{r}=+0,37, \mathrm{p}<0,04)$ та LF/HF ( $\mathrm{r}=+0,36, \mathrm{p}<0,04)$; вмістом у сироватці крові АКТГ та показником HFnorm $(\mathrm{r}=+0,44, \mathrm{p}<0,03)$. Зворотну кореляцію зафіксовано між вмістом у сироватці крові СТГ та показником HFnorm (r=0,37, $<<0,04)$; між вмістом у сироватці крові АКТГ та показниками LFnorm $(\mathrm{r}=-0,46, \mathrm{p}<0,03)$ $\mathrm{TaLF} / \mathrm{HF}(\mathrm{r}=-0,47, \mathrm{p}<0,02)$.

Виявлений у нашому дослідженні дисбаланс показників нейрогуморальної регуляції, що зберігається у хворих на СМ й у періоді реконвалесценції, на нашу думку, відіграє певну роль у затримці видужання цих осіб. Дані сучасної наукової літератури свідчать, що стрес-реакція на будь-яке ушкодження головного мозку, яка первинно $\epsilon$ адаптаційною, незабаром починає брати участь у механізмах патологічного процесу. Надмірні гормональні зміни викликають комплекс циркуляторних та метаболічних порушень [15], отже, первинно компенсаторна реакція стає «хворобою адаптації» [6]. Одну 3 провідних ролей у гуморальній регуляції при інфекційному процесі відіграє співвідношення АКТГ та СТГ, які контролюють не тільки процеси адаптації, але й шляхи одужання [10]. При високому рівні вільнорадикального окиснення переважає вплив АКТГ, який відноситься до стрес-активуючої системи, а при низькому рівні - СТГ, дія якого пов'язана зі стрес-лімітувальною системою [5]. Зі зниженням у сироватці крові вмісту СТГ та підвищенням рівня АКТГ корелює зниження когнітивних та мнестичних функцій [8]. На сучасному етапі нейроінфекція розглядається як хвороба дезадаптації, у розвитку якої суттєвого значення набуває автономна дизрегуляція, яку спричиняють, з одного боку, деструктивні зміни у ВНС, а з іншого - функціональні порушення, у тому числі пов'язані зі стресовими та емоційно-вегетативними над сегментарними регуляторними зрушеннями [14]. Дані літератури свідчать, що переважання парасимпатикотонії, недостатність активації симпатичної ланки ВНС на тлі зниження вегетативної реактивності свідчить про неадекватну реакцію на стрес та призводить до більш тривалого періоду одужання [12, 18].

Виявлені в нашому дослідженні зміни нейрогуморальної регуляції у хворих на СМ, що зберігаються й у періоді реконвалесценції, зумовлюють, на нашу думку, перспективність цього дослідження щодо подальшої розробки індивідуалізації патогенетичного лікування.

\section{Висновки}

1. У хворих на серозні менінгіти в динаміці з другого тижня лікування на тлі зменшення загальноінтоксикаційної й загальномозкової симптоматики маніфестують клінічні ознаки вегетативної дисфункції, що зберігаються в більшості осіб і в періоді реконвалесценції.

2. Функціональний стан вегетативної нервової системи в дебюті серозного менінгіту характеризується зниженням потужності в спектрах загальної вегетативної регуляції, гуморальної, симпатичної й парасимпатичної активності з розвитком вегетативного дисбалансу в бік ваготонії зі зниженням індексу вегетативного балансу. На тлі базисного лікування відбувається певне поліпшення цих параметрів, проте й у періоді реконвалесценції зберігається вегетативна дисфункція за рахунок низької потужності спектрів гуморальних впливів, симпатичної і парасимпатичної активності з підвищеною часткою парасимпатичних впливів у загальному спектрі вегетативної регуляції.

3. Зміни нейрогуморальної регуляції супроводжуються в розпал захворювання високим вмістом адренокортикотропного гормону та низьким вмістом соматотропного гормону, при цьому рівень останнього залишається зниженим і в періоді реконвалесценції.

Перспективи подальших досліджень. Виявлені в нашому дослідженні зміни нейрогуморальної регуляції у хворих на серозний менінгіт, що зберігаються й у періоді реконвалесценції, зумовлюють, на нашу думку, перспективність цього дослідження щодо подальшої розробки індивідуалізації патогенетичного лікування.

\section{Лiтература}

1. Бактеріальні гнійні менінгіти: сучасні проблеми діагностики і антибактеріальної терапії / I.O. Карпов, 
I.В. Юркевич [та ін.] // Інфекційні хвороби. - 2007. № 1. - C. $63-65$.

2. Богомолов Б.П. Диагностика вторичных и первичных менингитов / Б.П. Богомолов // Эпидемиол. и инфекц. болезни. - 2007. - № 6. - С. 44-49.

3. Вегетативные расстройства: Клиника, диагностика, лечение / Под ред. А.М. Вейна. - М.: ООО «Медицинское информационное агенство», 2003. $726 \mathrm{c}$.

4. Волошина Н.П. Клиническая характеристика современных хронических нейроинфекций (факторы риска, этиология, типы и варианты течения). Сообщение I / Н.П. Волошина, Т.В. Негреба, И.Л. Левченко // Укр. вісн. психоневрол. - 2009. - Т. 17, вип. 1 (58). - С. 10-14.

5. Гормональные сдвиги и интенсивность свободнорадикального окисления в крови больных с невропатиями лицевого нерва / Л.В. Говорова, Н.В. Скрипченко, Д.А. Голяков [и др.] // Ж. инфектол. - 2010. - Т. 2 , № 1. - С. 51-58.

6. Дизрегуляционная патология: руководство для врачей и биологов / [под ред. акад. Г.Н. Крыжановского]. М.: Медицина, 2002. - $631 \mathrm{c}$.

7. Исследование реактивности мозга в ответ на применение мексидола в комплексном лечении мозгового инсульта различной этиологии / В.И. Черний, Т.В. Островая, В.А. Белошапка [та ін.] // Сім. мед. 2005. - № 4. - C. 35-38.

8. Капустин Р.В. Корреляционный анализ клиникогормональных взаимоотношений у больных с дисциркуляторной энцефалопатией / Р.В. Капустин // Мед. сьогодні і завтра. - 2009. - № 1. - С. 130-133.

9. Крыжановский Г.Н. Патофизиология нейроиммунных взаимодействий / Г.Н. Крыжановский, С.В. Магаев // Патогенез. - 2010. - № 1. - С. 4-9.

10. Особенности ответа на воспалительный процесс у детей с высокой и низкой активностью свободнорадикального окисления в лимфоцитах в остром периоде заболевания в различных этнических группах / В.В. Иванова, Л.В. Говорова, А.В. Ерабская [и др.] // Ж. инфектол. - 2012. - Т. 4, № 3. - С. 46-52.

11. Патофизиология, диагностика и интенсивная терапия тяжелой черепно-мозговой травмы / [В.Н. Ельский,
А.М. Кардаш, Г.А. Городник и др.]; под ред. В.И. Черния. - Донецк: Новый мир, 2004. - 200 с.

12. Сергеенко Н.И. Функциональные взаимоотношения отделов вегетативной нервной системы в условиях общей анестезии / Н.И. Сергеенко. - Витебск, 2009. $236 \mathrm{c}$.

13. Сорокина М.Н. Вирусные энцефалиты и менингиты у детей / М.Н. Сорокина, Н.В. Скрипченко. - М.: Медицина, 2004. $-416 \mathrm{c}$.

14. Тайцлин В.И. Вегетативные нарушения у больных рассеянным склерозом / В.И. Тайцлин, Г.Д. Перцев // Укр. мед. часопис. - 2004. - № 5 (43). - С. 43-46.

15. Трошин В.Д. Стресс и стрессогенные расстройства. Диагностика, лечение и профилактика. - М.: Мед. информ. агентство, 2007. - $704 \mathrm{c}$.

16. EFNS guideline on themanagement of communityacquired bacterialmeningitis: reportofan EFNS Task Force on acute bacterial meningitis in older children and adults / A. Chaudhuri, P.M. Martin, P.G.E. Kennedy [et al.] // Eur. J. Neurol. - 2008. - Vol. 15, № 7. - P. 649-659.

17. Han K.S. Perceived stress, mood state, and symptoms of stress of the patient with chronic illness / K.S. Han // Taehan Kanho Hakhoe Chi. - 2003. - Vol. 33, № 1. - P. 87-94.

18. Lane J.D. Respiratory sinus arrhythmia and cardiovascular responses to stress / J.D. Lane, R.A. Adcock, R.E. Burnett // Psychophysiology. - 1992. - Vol. 29 (4). - P. 461-470.

19. Nicot A. Gender and sex hormones in multiple sclerosis pathology and therapy / A. Nicot // Front Biosci. - 2009. Vol. 14. - P. 4477-4515.

20. Reprogramming the host response in bacterial meningitis: howbest to improve outcome? / M. Van der Flier, S.P.M. Geelen, J.L.L. Kimpen [et al.] // Clinicalmicrobiologyreviews. - 2003. - Vol. 16, № 3. - P. 415-429.

21. Task Force of the European Sosiety of Cardiology and the North American Sosiety of Pacing and Electrophysiology.Heart Rate Variability. Standards of Measurements, physiological interpretation, and clinical use // Circulation. - 1996. - № 93. - P. 1043-1065.

22. Tomassini V. Sex hormones, brain damage and clinical course of Multiple Sclerosis / V. Tomassini, C. Pozzili // J. Neurol. Sci. - 2009. - Vol. 286. - P. 35-39.

\section{ОСОБЕННОСТИ ФУНКЦИОНАЛЬНОГО СОСТОЯНИЯ НЕЙРОГУМОРАЛЬНОЙ РЕГУЛЯЦИИ У БОЛЬНЫХ СЕРОЗНЫМИ МЕНИНГИТАМИ В ДИНАМИКЕ ЗАБОЛЕВАНИЯ}

\section{Д.А. Задирака, Е.В. Рябоконь, А.В. Абрамов}

Резюме. В работе показано, что у больных серозными менингитами в динамике заболевания на фоне уменьшения общеинтоксикационной и общемозговой симптоматики манифестируют клинические признаки вегетативной дисфункции, которые подтверждаются изменениями вариабельности сердечного ритма и гормональными изменениями, которые сохраняются у большинства больных в периоде реконвалесценции.

Ключевые слова: серозный менингит, вариабельность сердечного ритма, гормоны.

\section{FEATURES OF FUNCTIONAL STATE OF NEUROHUMORAL REGULATION IN PATIENTS WITH SEROUS MENINGITIS IN THE COURSE OF THE DISEASE}

\section{D.A. Zadyraka, E.V. Ryabokon, A.V.Abramov}

Abstract. The paper presents the fact, that in patients with serous meningitis in the course of the disease against the background of reducing intoxication and cerebral symptoms, clinical signs of autonomic dysfunction manifest and they are confirmed by the changes of heart rate variability and hormonal changes still remaining in the majority of patients during the period of convalescence.

Key words: serous meningitis, heart rate variability, hormones.

State Medical University (Zaporizhzhia)

Рецензент - проф. В.Д. Москалюк
Buk. Med. Herald. - 2014. - Vol. 18, № 1 (69). - P. 32-36 